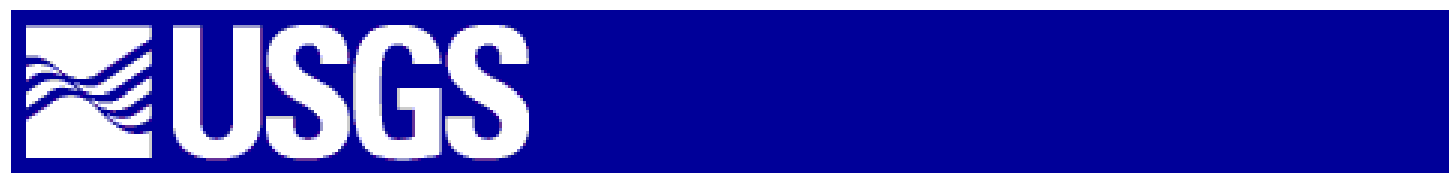

\title{
Modeling of the Climax Stock and related plutons based on the inversion of magnetic data, Southwest Nevada
}

By Geoffrey A. Phelps, Robert C. Jachens, Barry C. Moring, and Carter W. Roberts Open-File Report 2004-1345

2004

Prepared in cooperation with the U. S. Department of Energy

National Nuclear Security Administration, Office of Environmental

Management, Nevada Site Office,

under Interagency Agreement DE-AI52-01NV13944

Any use of trade, firm, or product names is for descriptive purposes only and does not imply endorsement by the U.S. Government.

Manuscript approved 9/22/2004

U.S. DEPARTMENT OF THE INTERIOR

U.S. GEOLOGICAL SURVEY 


\begin{abstract}
Two models of the Climax and Gold Meadows stocks were generated using a new method of magnetic inversion modeling based on the pseudogravity anomaly. The first model examined the shape of the two stocks and their connection at depth, concluding that the stocks are connected $-4000 \mathrm{~m}$ below the ground surface. The second model reexamined the shape and depth of the Climax stock using a two-layer model and new magnetic data collected from drill hole ER-8-1. Existing and new magnetic data support a model of a zoned pluton with increasing magnetization with depth. A model of a zoned pluton was generated and adjusted to fit the magnetic anomaly measured over the stock. The model has an upper layer that extends to a depth of $1,700 \mathrm{~m}$ and is magnetized at $0.06 \mathrm{~A} / \mathrm{m}$, and a lower layer that extends to a maximum depth of $7,600 \mathrm{~m}$ and is magnetized at $0.17 \mathrm{~A} / \mathrm{m}$. The model matches the outcrop data, but was unable to match the intercept of the Climax stock from drill hole ER-8-1.
\end{abstract}

\title{
Introduction
}

Two Cretaceous granitic stocks (Orkild and others, 1983) are exposed north of Yucca Flat within the Nevada Test Site, the Climax Stock, which outcrops at the northern apex of the basin, and the Gold Meadows stock, which outcrops approximately $14 \mathrm{~km}$ to the west. The rocks that comprise these stocks are similar in age and composition, and are thought to have a common source (Snyder, 1977). The granitic rocks in both the Climax and the Gold Meadows stocks contain significant amounts of magnetite, and thus produce distinctive magnetic anomalies that reflect their subsurface distribution. Because these granitic bodies may have hydrologic properties different from those of rocks they intrude, knowledge of their three-dimensional distribution in the subsurface will help constrain hydrologic models of the southward flow of ground water into Yucca flat.

The Climax stock is a Cretaceous granitic intrusive body exposed just north of Yucca Flat on the Nevada Test Site, southwest Nevada (figs. 1 and 2). The stock is characterized by exposures of quartz monzonite and granodiorite and is cut locally by sills and dikes of varying texture and composition. Chemically the quartz monzonite and granodiorite are similar, with the quartz monzonite containing more potassium feldspar, less biotite and plagioclase, and slightly less magnetite (Maldonado, 1977). The stock intrudes Paleozoic rocks from the Pogonip Group, which have a bulk density similar to that of the rocks forming the Climax stock (Maldonado, 1977; Phelps and others, 1999). Thus the Climax stock does not produce an observed gravity anomaly. The age of the stock is between 91 and 101 Ma (Orkild and others, 1983). Numerous drill holes and tunnels penetrate the stock, but only one drill hole, ER-8-1, is not spudded on the outcrop. It penetrates the stock the stock in the subsurface, providing one subsurface data point of the location of the contact of the stock.

The Gold Meadows stock is a Cretaceous granitic intrusive exposed approximately $14 \mathrm{~km}$ west of the Climax stock and $1.6 \mathrm{~km}$ north of Rainier Mesa. The stock is composed of granodiorite, quartz monzonite, and calc-alkaline granite, and has an age of approximately $91 \mathrm{Ma}$. The stock intrudes Paleozoic quartzites of similar density (Snyder, 
1977). Thus the Gold Meadows stock does not produce an observed gravity anomaly. No drill holes penetrate the contact between the stock and overlying rocks.

The purpose of this study is to examine whether or not a connection between the stocks exists at depth, to determine the shape of the Climax Stock at depth, and determine if either could form a significant barrier to groundwater flow. The stocks produce prominent magnetic anomalies, and one can use this information to define their shape. By estimating the stocks' magnetization from rock samples, the magnetic anomaly can be used to inversely model the three-dimensional shape of the bodies. This report emphasizes the study of the Climax Stock, since its shape is a necessary input to ongoing 3D modeling efforts funded by the DOE/NSO Environmental Restoration Division's Underground Testing Association (UGTA) Program.

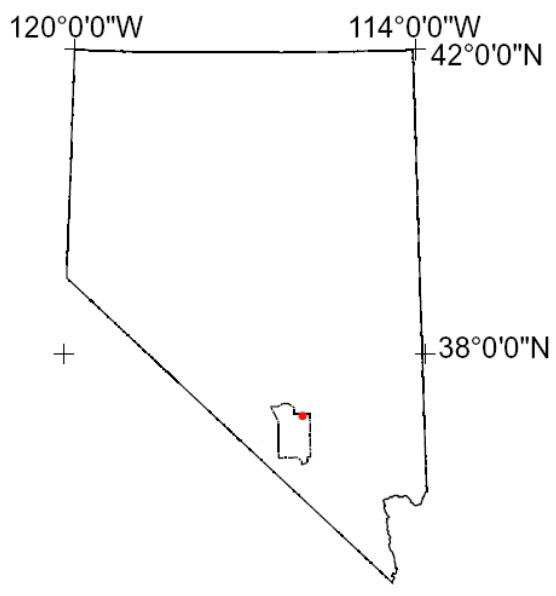

Fig. 1. Location of the Nevada Test Site (dashed line) and Climax and Gold Meadows Stocks (red dot) 

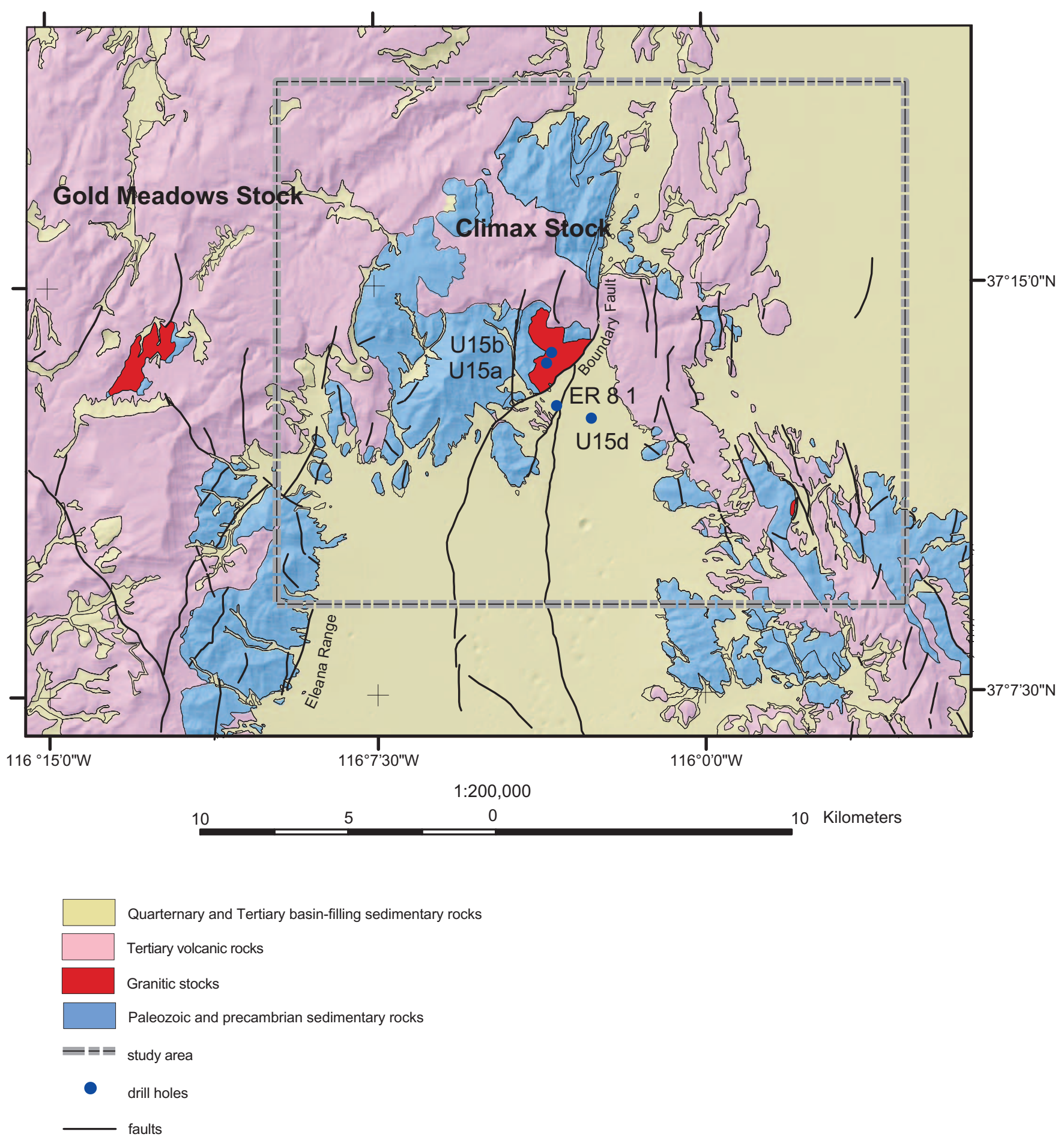

Figure 2. Shaded relief geologic map indicating location of major rock types in the vicinity of the Climax Stock 
The shape of the Climax stock was modeled twice in the past using magnetic inversion techniques, once in conjunction with investigations into the suitability of the stock as an underground testing site (Allingham and Zietz, 1962), and once as an investigation of the stock as suitable for the housing of a nuclear waste storage facility (Bath and others, 1983). The Gold Meadows stock was modeled once in the past, using gravity inversion techniques. Unfortunately, the shape of the stock cannot be distinguished from intruded Paleozoic rocks because the densities of the granitic rocks and the Paleozoic quartzites are too similar. The current work takes advantage of improved geophysical methods to model the shape of the stocks in the subsurface, for incorporation into a three-dimensional hydrostratigraphic model. This model is used to investigate of the local and regional hydrology, as part of the UGTA Program.

The Climax stock and the Gold Meadows stock both have a strong magnetic signature. The local magnetic anomaly values are high directly over the stocks. The spatial coincidence of the high values over the stocks, and the known magnetic properties of the quartz monzonite and granodiorite that make up the stocks, indicate that the large anomalies are due to the presence of the stocks at depth, and allows the subsurface shape of the stocks to be modeled. The effects of Paleozoic rocks are assumed to be negligible. Although the Eleana formation has been shown to be magnetic where exposed southwest of the stocks, the nearby Eleana Range shows no significant magnetic anomaly in the aeromagnetic survey compilation of McCafferty and Grauch (1997), nor did core samples from drill holes UE17e and UE16f, both located south of the study area in the Eleana range, (Appendix A) show any magnetization.

In this work two models were created using a new magnetic inversion technique that is based on the pseudogravity (Baranov, 1957). The technique models the pseudogravity anomaly, a transformation that converts the magnetic field to magnetic potential (Blakely, 1995), as if it were a gravitational anomaly, using the degree of magnetization in the granitic rocks in place of rock densities. The two models used different assumed magnetization values and had slightly different goals. The first model attempted to answer the question of whether the Climax stock and Gold Meadows stocks are connected at depth. The second model attempted to improve upon the shape of the Climax stock predicted by the first model by generating a two-layer model. This model took advantage of the change in magnetization with depth measured in the Climax stock, demonstrated by Bath and others (1983) and measured from the cuttings taken from drill hole ER-8-1 (this report).

This work contains four digital-only appendices that are available from the web site for this publication: http://pubs.usgs.gov/of/2004/1345. Appendix A contains magnetic susceptibility measurements collected from cores of selected drill holes. Appendices B through D are the results of different models of the Climax Stock and are described in later sections of this report.

\section{Previous work}

Allingham and Zietz (1962) modeled the Climax stock using the data from a magnetic survey flown in 1960. Assuming a constant magnetization, they modeled the 
stock as a series of cylinders, roughly pyramidal in shape, extending to a depth of approximately $4,000 \mathrm{~m}$.

Subsequent to the modeling of Allingham and Zietz (1962), drill hole UE15d reached the depth of $1,830 \mathrm{~m}$ without penetrating the Climax stock, which was predicted at a depth of approximately 1,400 m by the Allingham and Zietz (1962) model.

Bath and others (1983) developed a modified 5-prism model of the Climax stock based on a more recent magnetic survey than was available to Allingham and Zietz (Bath 1976). The 5-prism model assumes an increasing magnetization with depth. The shapes of the prisms are simplified blocks, with each of the deeper prisms larger than the previous, shallower prism.

\section{Magnetic data}

The source of magnetic data used in this study (fig. 3) was a compilation of several previous magnetic surveys (McCafferty and Grauch, 1997) that do not measure the magnetic anomaly in the vicinity of the climax stock with equal precision. The data sources in this area are a magnetic survey conducted over Timber Mountain in 1977 (U.S. Geological Survey, 1979), a compiled Naval Oceanographic survey (Bath and others, 1983), and a more recent survey conducted over Yucca Flat by Jet Propulsion Laboratory (JPL) (McCafferty and Grauch, 1997). The Timber Mountain data have a flight-line spacing $400 \mathrm{~m}$, collected at a nominal $122 \mathrm{~m}$ meters above the topography. The Naval Oceanographic survey data was flown over the Climax stock with a flight-line spacing of $1600 \mathrm{~km}$ and at a nominal height of $800 \mathrm{~m}$. The most recent Yucca Flat survey was conducted by JPL and had a $400 \mathrm{~m}$ flight-line spacing, flown a nominal $122 \mathrm{~m}$ above the topography. Both the Timber Mountain survey and the JPL survey have a relatively high resolution. However, the two surveys do not overlap. The new well ER-8-1 was located within a kilometer of the corner of the Timber Mountain survey, within $500 \mathrm{~m}$ of the gap between the two surveys. The gap between the Timber Mountain and JPL surveys was filled with the lower resolution data from the Naval Oceanographic survey. Therefore modeling in the vicinity of drill hole ER-8-1 will be hampered by both the lower resolution data and any smoothing performed during the compilation of the datasets.

The size of the model cells was chosen to be $300 \mathrm{~m}$, slightly finer than the flight-line spacing. Uncertainty in, and subsequent filtering of, the original data will smooth the very high-frequency component of the data; a finer resolution is not justified. As a consequence, high-frequency variation in the shape of the stock is below the resolution of this dataset. 


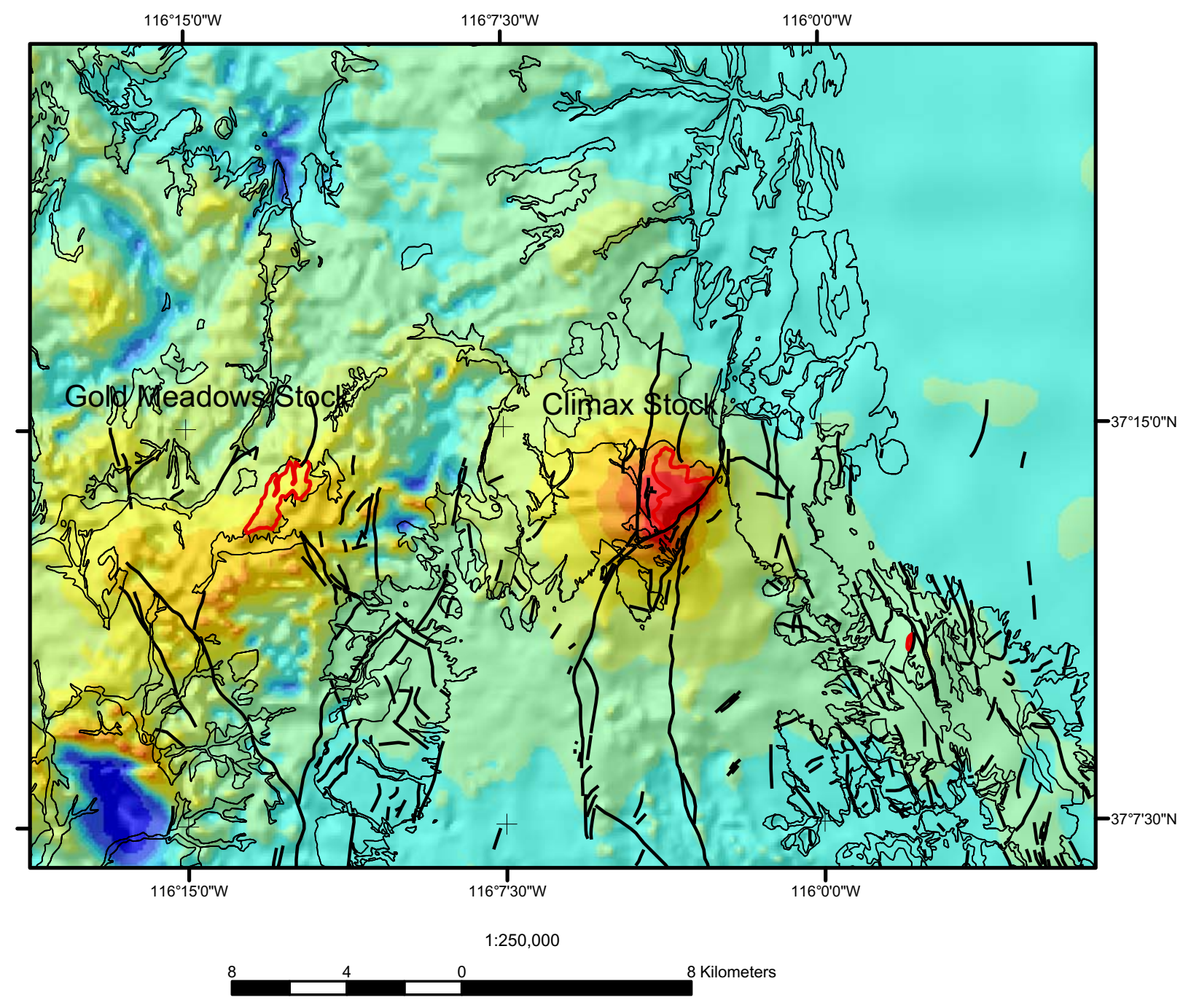

Magnetic Field Strength in nT

$\begin{array}{llll}\square & -2,020 & \text { to } & -800 \\ -799 & \text { to } & -500 \\ \square & -499 & \text { to } & -400 \\ -399 & \text { to } & -300 \\ \square & -299 & \text { to } & -200 \\ \square & -199 & \text { to } & -100 \\ \square & -99 & \text { to } & 0 \\ \square & 0 & \text { to } & 100 \\ \square & 100 & \text { to } & 200 \\ \square & 200 & \text { to } & 300 \\ \square & 300 & \text { to } & 400 \\ \square & \text { to } & 2,200\end{array}$

Figure 3. Areomagnetic anomaly over the Climax and Gold Meadows Stocks. Magnetism from McCafferty and Grauch, 1997, Geology from Wahl and others (1997) 


\section{Physical property data}

The total magnetization of a rock is given by the induced magnetization plus the remnant magnetization, but in plutonic rocks remnant magnetization is often not a significant factor. Measurements of the remnant magnetization from samples of quartz monzonite and granodiorite from the Climax Stock indicate remnant magnetization accounts for less than $13 \%$ of the total magnetization (Allingham and Zietz, 1962). The remnant magnetization can therefore be ignored, and the total magnetization can be approximated from the induced magnetization. Because of the similarity of the rocks from the Climax and Gold Meadows stocks, the remnant magnetization in the Gold Meadows stock is assumed to be negligible as well.

The magnetic susceptibility of 24 samples from drill hole U15a were measured, and show an increase with depth from approximately $0.76 \mathrm{Amps} / \mathrm{meter}(\mathrm{A} / \mathrm{m})$ to $1.5 \mathrm{~A} / \mathrm{m}$, corresponding to a magnetite concentration of $0.8 \%$ and $1.4 \%$, respectively (Allingham and Zietz, 1962). Allingham and Zietz (1962) interpreted the trend as both a lower concentration and alteration of magnetite in the quartz monzonite and a higher concentration of magnetite in the deeper granodiorite samples.

Bath and others (1983) measured the magnetic susceptibility of over 650 samples of both quartz monzonite and granodiorite from both drill holes and tunnels cut into the Climax stock. Both quartz monzonite and granodiorite show increasing magnetization with depth. The most thorough part of this effort was conducted on sampling from drill hole U15b-1, where magnetic susceptibility was measured on 351 samples collected from the surface to a depth of $533 \mathrm{~m}$ (fig. 4). The magnetization of the Climax stock increases roughly linearly with depth at least to a depth of $533 \mathrm{~m}$. Bath and others (1983) fit a linear model to the data that increases at roughly $0.0019 \mathrm{~A} / \mathrm{m}$ per meter with depth and has a correlation coefficient of 0.75 .

Bath and others (1983) related the increase in magnetization to an increase in the percentage of magnetite present in the stock, based on 13 thin sections made from samples from drill hole U15b-1 from various depths in the stock. Visible alteration of magnetite to hematite occurred only above a depth of $30 \mathrm{~m}$. Below this the magnetite content increased to $0.65 \%$, and correlated with the increase in magnetization. In the absence of any measurements of the magnetic properties of the Gold Meadows stock, an average magnetization was estimated for these rocks by comparing the magnetic anomaly over the Gold Meadows stock to the magnetic anomaly over the Climax stock. The anomaly gradients along the lower south and southeast flanks of the two anomalies are similar, suggesting that the bodies extend to similar depths. It was assumed that these igneous bodies were rooted at the same depth. Three-dimensional magnetic modeling was used to determine that, to account for the measured magnetic anomaly over the Climax stock, the granitic rocks had to extend to a depth below the outcrop of about $7.5 \mathrm{~km}$. Additional modeling showed that to account for the magnetic anomaly over the Gold Meadows stock with a body that extended to the same depth of $7.5 \mathrm{~km}$ required an average magnetization of $0.8 \mathrm{~A} / \mathrm{m}$, or roughly half that of the Climax stock. 


\section{New data from Well ER-8-1}

The drill hole ER-8-1 penetrated the Climax stock granodiorite at a depth of 539 meters. ER-8-1 bottomed at 873 meters, drilling through 334 meters of granodiorite. No core was taken in this interval, but abundant cuttings were available. The magnetic susceptibility of boxes of cuttings from the granodiorite was measured with a hand-held susceptibility meter over the depth interval of the granodiorite (fig. 4).

Three hundred forty-five measurements were taken at 70 depth locations, sampling every 10 to 20 meters. Measurements were repeated at least five times at each sampled depth interval for all but the 10 deepest intervals, which had three repeat measurements each. These measurements were averaged to yield a given magnetic susceptibility at a given depth. These were then converted from magnetic susceptibility to magnetization, and thus comparable to measurements taken by Bath (Bath and others, 1983), by using the formula described below (from Bath and others, 1983)

$$
\begin{aligned}
& J_{i}=B^{*} S / \mu, \quad \text { where } S=\text { average susceptibility } \\
& \mathrm{B}=\text { earth average magnetic field } \\
& \mu \text { is a constant } \\
& \mathrm{J}_{\mathrm{i}}=\text { induced magnetization } \\
& \mathrm{J}_{\mathrm{t}}=\text { total magnetization } \\
& J_{i}=51900 * 10^{-9} * S /\left(4 * \pi * 10^{-7}\right)=519 * S / 4 \pi \\
& J_{t}=J_{i}(1+Q) \text {, where } \mathrm{Q}=0.15 \text { for granodiorite }
\end{aligned}
$$

The two datasets are plotted together in figure 4. Based on the location of the drill holes relative to the shape of the magnetic anomaly over the Climax stock, drill hole and U15b-1 is sampling the center of the stock, and drill hole ER-8-1 is sampling the flank of the stock. Two observations can be made from this figure. First, data from both the center of the stock and the flank of the stock show a linear trend of increasing magnetization with depth. Second, the new data from drill hole ER-8-1 shows a trend that increases less rapidly than for samples following the predicted trend described Bath and others (1983) and that the magnitude of the induced magnetization is at the low end of the range of the previous data. This less-rapid increase of magnetization with depth may be due in part to the data collection method, however. Measurements from cuttings will yield susceptibility readings two to three times lower than those from whole-rock samples (J. Hillhouse, personal communication). If a correction factor of 2.5 is applied to the data, the data are consistent with the range of data values from well U15b-1 (fig. 5), with a slightly lower slope. The linear trend with depth shown in both datasets suggests a model of mineralization within the Climax stock. The data support a vertically-zoned pluton, where magnetization increases with depth. The lower slope of the data from well ER-8-1 also permit a concentrically-zoned pluton, where one would expect the slope to be lower because of the shallower angle of penetration of well ER-8-1 as it sampled subparallel to the flank of the stock. 


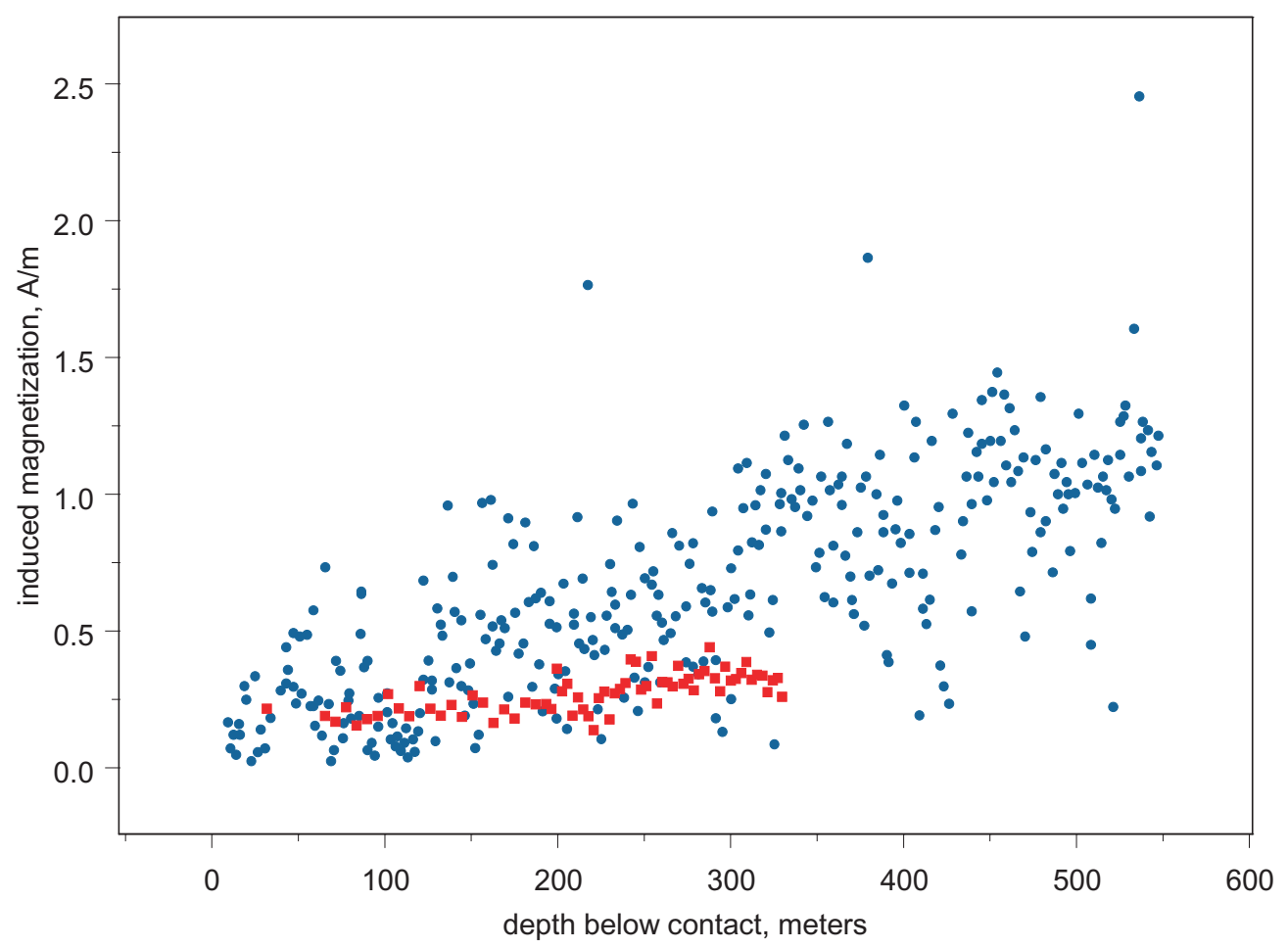

Figure 4. Induced magnetism measured from samples from drill-holes U15b-1 (blue, Bath and others, 1983) and ER-8-1 (red, this paper).

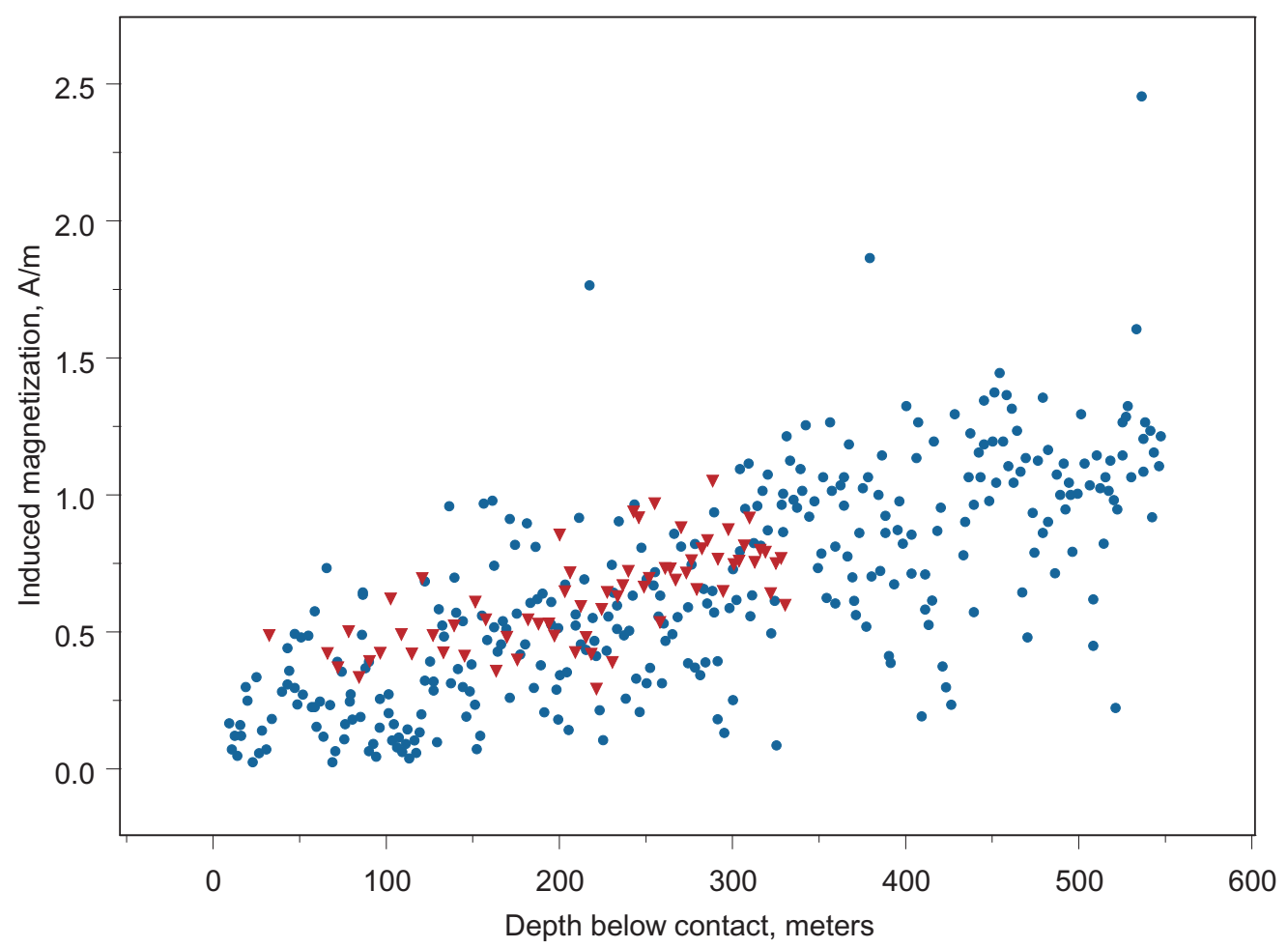

Figure 5. Induced magnetism measured from samples from drill-holes U15b-1 (blue, Bath and others, 1983) and ER-8-1 with a correction factor of 2.5 applied (red, this paper). 


\section{Method}

Two models were created in this study. The first uses a new technique of inverting the pseudogravity to estimate the depth of the Climax and Gold Meadows stocks and the possible connection between the two bodies. After drill hole ER-8-1 demonstrated that the Climax stock was approximately $600 \mathrm{~m}$ shallower than predicted at the location of the drill hole, a second model was created to provide a second estimate of the depth to the Climax stock. The second model used a modified method of the pseudogravity inversion technique.

The Climax stock and Gold Meadows stock were modeled based on four assumptions. First, the large magnetic anomalies centered on the outcropping stocks were assumed to be caused solely by the granitic rocks of the stocks. Second, the difference in magnitude between the larger anomaly over the Climax stock and the smaller anomaly over the Gold Meadows stock was assumed to be due to a difference in magnetization between the two stocks. Third, the lateral change in magnetization between the two stocks was assumed to be gradational, since the magnetic anomalies do not indicate any abrupt magnetic boundaries between the two outcrop areas. Fourth, the magnetization caused by magnetic tuffs outcropping in the area was assumed to be eliminated by smoothing the high-frequency anomalies that exist over the outcropping magnetic tuffs.

To estimate the subsurface shape of the Climax and Gold Meadows stocks the magnetic anomaly (McCafferty and Grauch, 1997) was transformed to a pseudogravity anomaly (Baranov, 1957), which can be used to define the shape of a rock body based on the rock's magnetic properties. The magnetic properties of the body were modeled to produce a depth to the surface of the body, the boundary between the magnetic stock and the surrounding non-magnetic country rock. By inverting the pseudogravity anomaly the depth and shape of the Climax and Gold Meadows stocks were estimated.

The second model attempted to improve on the shape of the Climax stock predicted by the original model by modifying the procedure. The second model attempted to explicitly model the magnetic anomaly caused by magnetic tuffs in the vicinity so that these effects could be accounted for, and to improve the estimation of the shape of the Climax stock by developing a two-layer model that takes advantage of the knowledge that the magnetization in the stock increases with depth. Beginning with the magnetic anomaly of McCafferty and Grauch (1997), the anomaly was upward-continued to a horizontal plane, $2400 \mathrm{~m}$ in elevation. Upward continuation of a magnetic anomaly allows the anomaly to be related to a given horizontal datum. The upward-continued magnetic anomaly was then modeled according to the following procedures.

The magnetic anomaly includes the effects of all magnetic rocks in the vicinity of the observation points. Therefore, the first step in the analysis process is to try to isolate the anomaly caused solely by the Climax stock by subtracting the portion of the anomaly generated by other sources. However, this requires that the shape and magnetization of other sources be estimated. Tertiary tuffs from the Timber Mountain, Paintbrush, Crater Flat, and Belted Range Groups comprise the bulk of the non-granitic magnetic rocks in the study area. Average magnetic properties for these tuffs have been published (Grauch and others, 1997). 
The tuffs in the vicinity of the Climax stock are predominantly flat-lying based on the outcrop patterns of the geologic map (Sargent and Orkild, 1973). Because the shape of the tuffs could be estimated and their physical properties are known, an attempt was made to subtract the magnetic contribution of the tuffs. However, several difficulties arose. Some tuffs pinch out, and others interfinger in the subsurface over large, unexposed areas. Variations in thickness across units become apparent when the data are modeled in three dimensions. Additionally, Hudson (1997) noted that earlier mapping to the south at Massachusetts Mountain (Hinrichs and McKay, 1965) mistakenly mapped tuffs in the upper sections of the Rainier Mesa member of the Timber Mountain tuff as a lower section of the Ammonia Tanks member. These units have opposite magnetic polarities, and if mis-mapped in northern Yucca Flat would significantly alter the predicted magnetic anomaly produced by the tuffs. A qualitative inspection of the anomalies in the Climax Stock study area suggest this may well be the case as significant areas of what are mapped as the Ammonia Tanks member appear to have anomalies characteristic of reversely magnetized rocks. Based on the large potential for error, the authors decided the magnetic anomalies caused by the tuffs could not be characterized with confidence, and therefore proceeded with modeling with the realization that the tuffs will introduce greater uncertainty into the model.

Based on the quantitative values for magnetization of Allingham and Zietz (1962) and Bath (1983) discussed in the previous sections, a reasonable conceptual model for the stock is a zoned plutonic body with an increase in magnetite concentration up to $1.5 \%$ at depth. Using the published data (Bath, 1983), a linear model that describes the increasing magnetization with depth was developed. This continuous model was simplified by modeling the Climax stock in two sections, a lower, more magnetic section, and a higher, less magnetic section. The maximum magnetization for the lower portion of the stock in this model is approximately $02.35 \mathrm{~A} / \mathrm{m}$, and for the upper portion of the stock approximately $01.22 \mathrm{~A} / \mathrm{m}$. Mean values for each are approximately 1.8 and 0.6 , respectively. Modeling showed that the best results were obtained by a slightly lower value for the base of the stock. The model of the stock has a lower portion with a mean value of $1.7 \mathrm{~A} / \mathrm{m}$ below a depth of $1,700 \mathrm{~m}$, and a mean value of $0.6 \mathrm{~A} / \mathrm{m}$ from $1,700 \mathrm{~m}$ depth to the surface (fig. 6, step 6).

The shape of the stock was modeled from the pseudogravity anomaly in several steps (fig. 6). First, an inverse modeling procedure was used that increases the elevation of an array of vertical prisms, from a fixed-plane at depth, until the residual error between the measured anomaly and the anomaly caused by the vertical prisms is minimized. This is a preliminary model for a magnetically homogeneous body. Second, to approximate the apparent magnetic zonation in the stock, the upper portion of the preliminary model was removed. Next, the contribution of the magnetic anomaly from this truncated model was then found by forward modeling. The difference between this and the total anomaly is the residual anomaly produced by the less-magnetic upper portion of the stock. The upper portion of the stock was inversely modeled from the residual anomaly. Finally, the two individual portions of the stock were then summed and compared to the stock where it outcrops. 


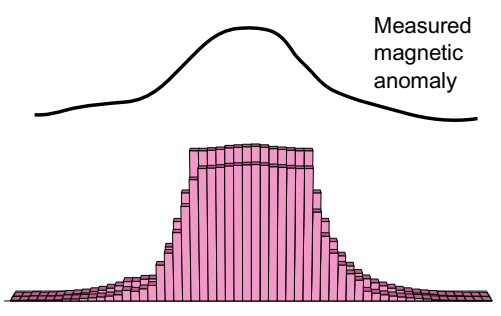

Step 1. Find the shape of a stronglymagnetized body that fits the anomaly

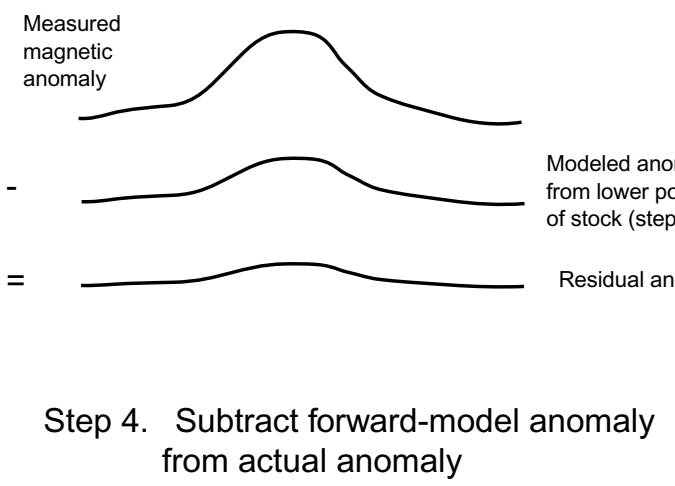

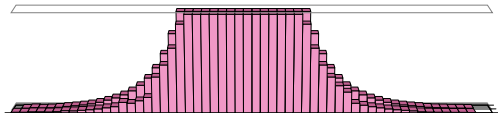

Step 2. Remove less magnetic, upper portion of stock

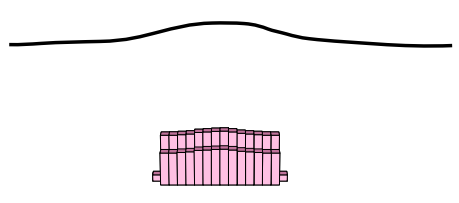

Step 5. Model weakly magnetized upper portion of stock, starting at depth of lower stock

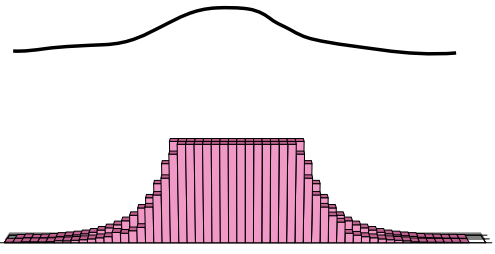

Step 3. Forward model remaining lower portion of the stock

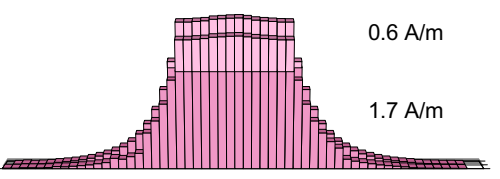

Step 6. Add upper and lower model together and compare to outcrop and well data

Figure 6. Schematic of the six steps used to model the shape of the Climax Stock. Numbers in Step 6 are values in amps/meter used in constructing the final model of the stock. 


\section{Results}

The first model, that of the elevation of the Climax and Gold Meadows stocks generated from inversion of the pseudogravity anomaly, is shown in figure 7. The raster dataset for this model is included in Appendix B. The three-dimensional model suggests that these two stocks represent cupolas projecting upward from a larger single intrusion $4,000 \mathrm{~m}$ or more beneath the surface. The intrusion most likely extends northwest of the outcrop of the Climax stock. However, in this area the magnetic anomalies from the Tertiary volcanic rocks confuse the magnetic image of the intrusion, so the shape of the intrusion is difficult to determine. The bottom surface of this model is flat and at an elevation of approximately $-5 \mathrm{~km}$. This could reflect the actual bottom of the magnetic granitic rocks, or the elevation at which the granitic body flattens and extends laterally outside the bounds of the magnetic data. The magnetic anomalies cannot be used to distinguish between these two cases.

There is no evidence, either in the shape of the granitic intrusion inferred from the magnetic data or in the distribution of magnetic properties required to satisfy the magnetic anomalies, for a fault with major strike-slip or dip-slip offset separating the Climax and Gold Meadows stocks. A fault with an offset of a few kilometers or more would be visible from the inferred shape or properties of the intrusion. Faults with smaller offset could exist and not be revealed by the magnetic model.

While the first model revealed important information on the nature of the connection between the Climax and Gold Meadows stocks and the subsurface shape of the bodies, subsequent information from drill hole ER-8-1, located to the southeast of the outcrop of the Climax stock, showed that the model overestimated the depth to the stock at that location. Drill hole ER-8-1 penetrated the Climax stock at a depth of $539 \mathrm{~m}$, where the first model of the Climax stock predicted the depth to be approximately $1100 \mathrm{~m}$. Possible reasons for such a large error in the prediction are discussed subsequently. 


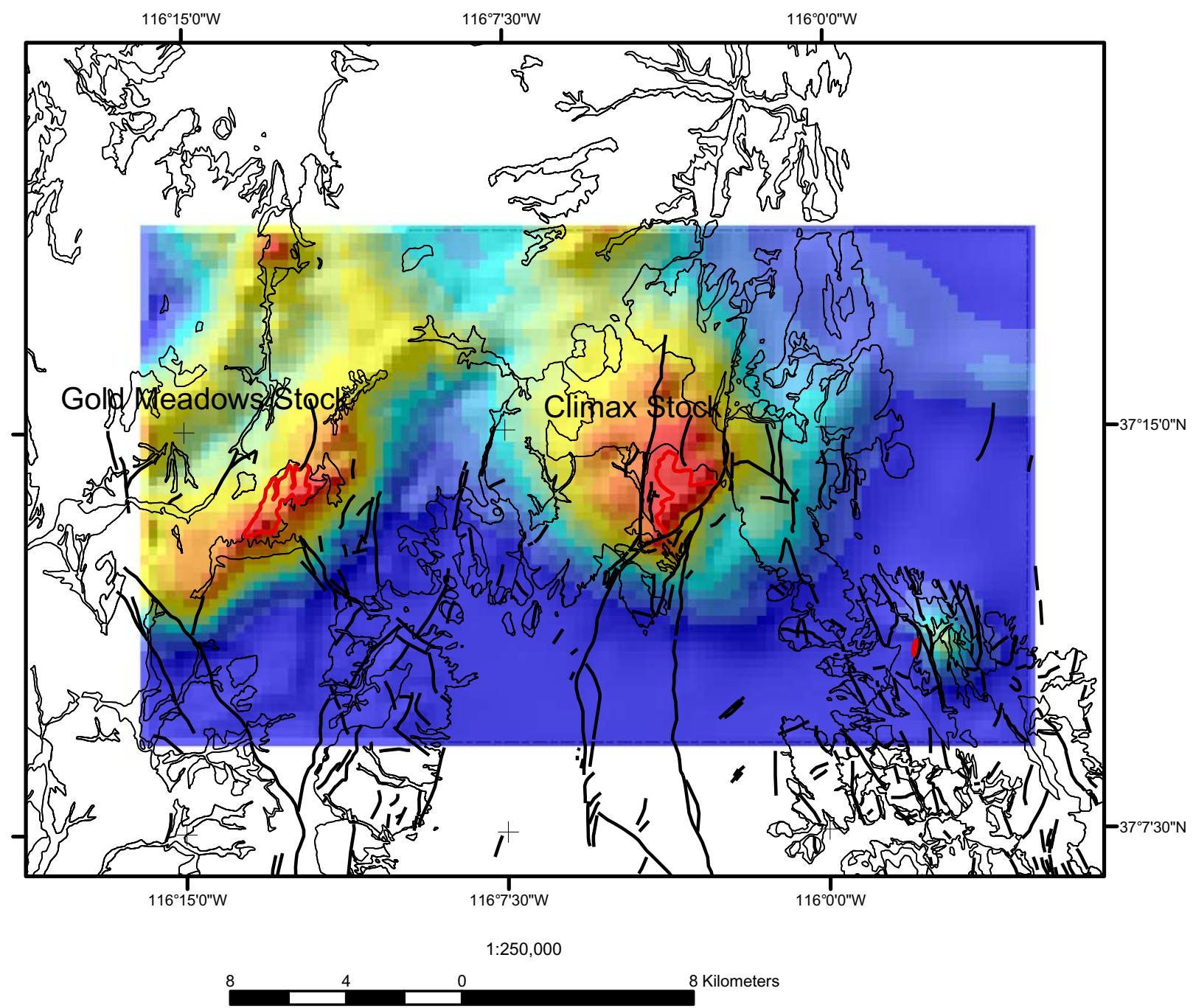

Modal surface elevation in meters

$\begin{array}{lll}\square-5,694 & \text { to } & -4,500 \\ -4,500 & \text { to } & -4,000 \\ -4,000 & \text { to } & -3,500 \\ \square-3,500 & \text { to } & -3,000 \\ \square-3,000 & \text { to } & -2,500 \\ \square-2,500 & \text { to } & -2,000 \\ \square-2,000 & \text { to } & -1,500 \\ \square-1,500 & \text { to } & -1,000 \\ \square-1000 & \text { to } & 0 \\ \square 0 & \text { to } & 500 \\ \square 500 & \text { to } & 1,000 \\ \square 1,000 & \text { to } & 1,500 \\ \square 1,500 & \text { to } & 2,015\end{array}$

Figure 7. Shaded relief view of the first model, including both the Climax and Gold Meadows stocks (red outlines), showing the conection of the stocks at depth. Geology from Wahl and others (1997) 
The second model attempted to improve upon the first by modeling the Climax stock in two stages, taking advantage of the inferred change in magnetization of the stock with depth. In order to use this technique, a model of the magnetization of the upper and lower parts of the stock, and where to separate the two, must be decided. The model that best fit both the outcrop data and the measured magnetic anomaly is shown in figure 6, step 6. The raster dataset for the model surface is included in appendix $\mathrm{C}$. The solution is nonunique; however, it is a solution that fits the available magnetic data, outcrop data, and geologic concepts of the mineralogical structure of the stock. None of the models generated were able to reproduce the location of the stock in the subsurface at drill hole ER-8-1. All modeling efforts in this report produced results that placed the surface several hundred meters below the actual depth known from drill hole ER-8-1.

There are four conceivable reasons that the modeling overestimated the known depth of the Climax stock at drill hole ER-8-1. One, our modeling procedure accounted for downward zonation of the pluton but could not accommodate zonation inward from the contact with country rock. If the outer margin of the stock were less magnetic than the core our procedure would overestimate the depth of the stock along its margins. This is consistent with the downwardly increasing magnetization observed in drill hole ER-81. Coreward zonation of the stock would also be consistent with the two to three-fold lower magnetic susceptibility values measured in drill hole ER-8-1. Because ER-8-1 was drilled sub-parallel to the edge of the stock, a coreward zonation would appear as a more gradual increase in magnetization due to the lower angle of incidence with the gradient of magnetization.

The second possible reason for a mismatch in the data is the location of drill hole ER-8-1 relative to the edges of the airborne geophysical surveys. As previously mentioned, the drill hole is located in the corner of the Timber Mountain survey, subject to edge effects from both the east and the south. This coincides with the down-dropping of the southeastern portion of the Climax stock along the Boundary fault. The steepest gradient in the magnetic anomaly in this area would define the boundary of the stock. The location of the gradient, however, cannot be resolved effectively because of edge effects and the gap between the Timber Mountain survey and the JPL survey that was filled with lower resolution data. Supplementary information is needed to fill the gap in the data.

A third possibility contributing to the mismatch in predicted location of the Climax stock in the subsurface is due to the steep dip angle of the contact of the stock with surrounding rocks. The high angle of the stock margin amplifies minor horizontal location errors, because a small change in the horizontal location of the contact results in a large change in its vertical location. A shift of less than $1 \mathrm{~km}$ to the southeast could account for the mismatch in drill hole ER-8-1.

A fourth possible reason for the mismatch in predicted location of the Climax stock in the subsurface is that drill hole ER-8-1 intercepted an anomalous lobe of granodiorite not associated with the main body of the stock. The magnetic data do not have a fine enough resolution to allow the distinction of the high-frequency magnetic data that smaller bodies would generate in the magnetic anomaly. The model would predict the main body of the stock, but would not be able to predict smaller bodies. 


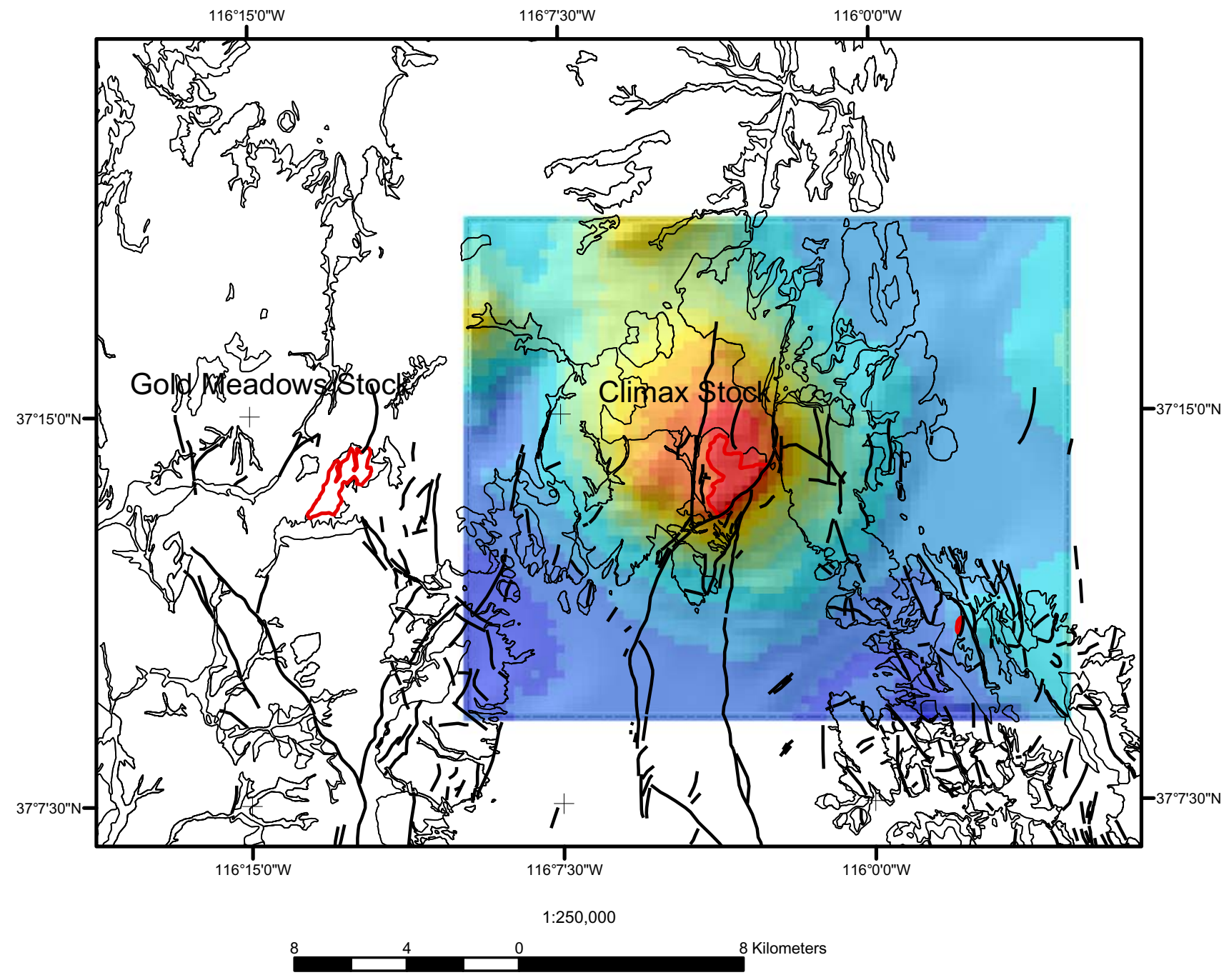

Modal surface elevation in meters

\begin{tabular}{|c|c|c|c|}
\hline 口 & $-4,600$ & to & $-4,500$ \\
\hline 口 & $-4,500$ & to & $-4,000$ \\
\hline E & -4000 & to & $-3,500$ \\
\hline$\square$ & $-3,500$ & to & $-3,000$ \\
\hline$\square$ & -3000 & to & $-2,500$ \\
\hline$\square$ & $-2,500$ & to & $-2,000$ \\
\hline$\square$ & $-2,000$ & to & $-1,500$ \\
\hline$\square$ & $-1,500$ & to & $-1,000$ \\
\hline$\square$ & -1000 & to & -500 \\
\hline$\square$ & -500 & to & -0 \\
\hline$\square$ & 0 & to & 500 \\
\hline$\square$ & 500 & to & 1,000 \\
\hline ㄷ & 1,000 & to & 1,500 \\
\hline E. & 1,500 & to & 1,832 \\
\hline
\end{tabular}

Figure 8. Shaded relief view of the final model of the Gold Meadows stock (red outline). Geology from Wahl and others (1997) 
However, since drill hole ER-8-1 intercepted over 300 m of granodiorite, this alternative seems unlikely.

Because the depth to the stock is being incorporated into a three-dimensional geologic model, it was of primary importance to fit the surface to the drill hole information. This could not be done using the existing data and modeling techniques, for the reasons discussed previously. The drill hole offers an opportunity to add supplementary information to the model so that the stock can be precisely located at ER8-1. The authors assumed that the drill hole intercepted the main body of the stock and not an anomalous lobe disassociated from the main body, and interpreted the magnetic data as representing the overall shape of the Climax stock, especially the more magnetic core. If magnetization decreases towards the edges of the stock, a reasonable procedure would be to buffer (add a rind of material to) the existing model of the stock out to a distance of the intercept in drill hole ER-8-1. This would adjust for the decrease in magnetization due to internal zonation and match the location of the edge of the stock in the data gap with the existing subsurface data (fig. 8). The raster dataset representing this interpretation is included in appendix D.

The final version of the second model of the upper surface of the Climax stock was the result of buffering $400 \mathrm{~m}$. This surface passed through the drill hole intercept and matched the outcrop data to within $100 \mathrm{~m}$. The shape of the model in outcrop is smoother than the actual outcrop due both to the size of the data cells in the model and the tendency of potential field inversions to smooth surfaces. This interpretation is a compromise between modeling the stock based on a simplification of its magnetic properties and assumed geologic structure, and fitting the result to the known data points.

\section{Uncertainty}

The uncertainty associated with the model surfaces is difficult to assess because independent information on the position of the surface is limited. Tests using different magnetizations and examination of the limited shallow wells that constrain the position of the granitic bodies initially suggested an uncertainty of $+/-20 \%$ of the bodies' predicted depth, but always at least $+/-300 \mathrm{~m}$. Thus, the uncertainty in the elevation of the saddle between the Climax and Gold Meadows stocks (with a depth below the surface of $\sim 4,000$ m) would be $+/-800 \mathrm{~m}$.

Data from drill hole ER-8-1 and results from the subsequent two-tier modeling of the Climax stock suggest that the model overestimates the depth to the surface of the stock, and that the minimum uncertainty should be raised to at least $+/-400 \mathrm{~m}$. The areas north and west of the Climax stock, where the deposition of magnetic Tertiary volcanic tuffs complicates the magnetic anomaly, will have a higher uncertainty. Unfortunately, this uncertainty is cannot be quantitatively estimated until the effects of the magnetic tuffs can be quantitatively estimated. 


\section{Conclusion}

Two models of the depth to the granitic stocks, the Climax stock and the Gold Meadows stock, were generated using a new technique that inverts the pseudogravity anomaly. The first model estimated the depth and shape of both the Climax and Gold Meadows stocks, examining their connection at depth. The results indicate that these two stocks represent cupolas projecting upward from a larger single intrusion at least $4,000 \mathrm{~m}$ beneath the surface, and that the stocks are not offset by a large fault.

The second model reexamined the depth and shape of the Climax stock by modeling the stock in two sections. The second model used existing magnetic data and new physical property and the lithologic data collected at drill hole ER-8-1 to improve the characterization of the magnetization within the stock. A two-layer model was generated based on a conceptual model of the spatial structure of the magnetic mineralogy of the stock. The model was unable to match the intercept in drill hole ER-81 , probably due to a combination of the decrease in magnetization towards the edges of the stock and the location of the drill hole at survey boundaries. The existing magnetic model is representative of the more magnetic central portion of the stock. The lessmagnetic outer portions were created by buffering the existing magnetic model to fit the existing intercept in drill hole ER-8-1. This interpretation is probably a reasonable representation of the shape of the stock at depth. 


\section{References}

Allingham, J. W., and Zietz, Isidore, 1962, Geophysical data on the Climax stock, Nevada Test Site, Nye County, Nevada, Geophysics, v. 27, no. 5, pp599-610.

Baranov, V., 1957, A new method for interpretation of aeromagnetic maps: pseudogravimetric anomalies, Geophysics, v.2, no. 2, pp. 59-383.

Barnes, Harley, Christiansen, R.L., and Byers, F.M. Jr., 1965, Geologic map of the Jangle Ridge quadrangle: U.S. Geological Survey Geologic Quadrangle Map GQ-363.

Bath, G.D., 1976, Interpretation of magnetic surveys in intermontane valleys at Nevada and southern New Mexico: U.S. Geological Survey Open-file Report 76-440, 36p.

Bath, G.D., Jahren, C.E., Rosenbaum, J.G., and Baldwin, M.J., 1983, Magnetic investigations, in U.S. Geological Survey, Geologic and geophysical investigations of the Climax Stock intrusive, Nevada: U.S. Geological Survey Open-file Report 83-377, p. 4077.

Blakely, R.J., 1995, Potential Theory in Gravity and Magnetic Applications: Cambridge University Press, New York, NY, 441 p.

Grauch, V.J.S., Sawyer, D.A., Fridrich, C.J., and Hudson, M.R., 1997, Geophysical interpretations west of and within the northwestern part of the Nevada Test Site, U.S. Geological Survey Open-File Report 97-476, 45 p.

Hinrichs, E.N., and McKay, E.J., 1965, Geologic Map of the Plutonium Valley Quadrangle, Nye and Lincoln Counties, Nevada, U.S. Geological Survey Geological Quadrangle map GQ-384.

Hudson, M.R., 1997, Structural geology of the French Peak accommodation zone, Nevada Test Site, southwestern Nevada: U.S. Geological Survey Open-File Report 9756, $26 \mathrm{p}$.

Maldonado, F., 1977, Summary of the geology and physical properties of the Climax Stock, Nevada Test Site: U.S. Geological Survey Open-File Report 77-356, 27 p.

McCafferty, A.E., and Grauch, V.J.S., 1997, Aeromagnetic and gravity anomaly maps of the southwestern Nevada volcanic field, Nevada and California: U.S. Geological Survey Geophysical Investigations Map GP-1015, scale 1:250,000.

Orkild, P.P., Townsend, D.R., and Baldwin, M.J., 1983, Geologic investigations, in U.S. Geological Survey, Geologic and geophysical investigations of the Climax Stock intrusive, Nevada: U.S. Geological Survey Open-file Report 83-377, p. 1-24. 
Sargent, K.A., and Orkild, P.P., 1973, Geologic map of the Wheelbarrow Peak-Rainier Mesa area, Nye County, Nevada, U.S. Geological Survey Miscellaneous Geologic Investigations Map I-754.

Snyder, R.P., 1977, Geology of the Gold Meadows stock, Nevada Test Site: U.S. Geological Survey Report USGS-474-179 [Area 12-26], 10 p.

U.S. Geological Survey, 1979, Aeromagnetic map of the Timber Mountain area, Nevada: U.S. Geological Survey Open-File Report 79-587, scale 1:62,500

Wahl, R.R., Sawyer, D.A., Carr, M.D., Minor, S.M., Cole, J.C., Swadley, W.C., Laczniak, R.J., Warren, R.G., Green, K.S., and Engle, C.M., 1997, Digital geologic map database of the Nevada Test Site area, Nevada: U.S. Geological Survey Open-File Report 97-140, scale 1:100,000, 47 p. 